Volume 6, Number 1, 2020

\title{
Analysis of Eddy-Current Testing and Metallographic Examinations for Corrosion Damages of Heat Exchanging Tubes in NPP Steam Generators
}

\author{
Tetiana Kovalenko, Stepan Lys ${ }^{*}$, Volodymyr Vostres \\ Lviv Polytechnic National University, 12 S. Bandera St., Lviv, 79013, Ukraine
}

Received: January 16, 2020. Revised: April 21, 2020. Accepted: May 07, 2020.

(C) 2020 The Authors, Published by Lviv Polytechnic National University.

\begin{abstract}
This paper represents the mechanism for corrosion damages of heat exchanging tubes (HET) of a steam generator PGV-1000 for various operational conditions. It was determined that corrosion damages locate mainly at the bottom of the steam generator bundled tubes. An investigation into the corrosion damages of HET was conducted in terms of PGV-1000 steam generator. The results of eddy-current testing (ECT) for steam generator HET performed by two different ECT systems "TEDDY-8", "MIZ-30" were analyzed and compared to the results of metallographic examination of defects. It was determined that the percentage of rusted metal according to the metallography data in the absolute majority of analyzed defects surpassed the ECT ones. The difference is equal to 10-15\% in most cases and up to $25 \%$ in some cases. It was proved that the thin-walled HET should not have significant or penetrating defects for ensuring the reliable operation of PGV-1000 HET, which is the most important task to do at a nuclear power plant (NPP).
\end{abstract}

Keywords: steam generator; heat-exchanging tubes; corrosion defects; eddy-current testing; metallographic examinations.

\section{Formulation of the research problem}

PGV-1000 steam generator (SG) in a power-generating unit of a nuclear power plant (NPP) with pressurized water reactor (water-water energetic reactor (WWER)) is one of the most important and significant elements for reactor safety. Cracks and further development of corrosion defects in heat-exchanging tubes (HET) in an SG may lead to depressurization of the primary coolant circuit of a reactor plant. The main reason behind HET damage is stressed corrosion cracking caused by a joint effect of tensile stress and concentrated solution of corrosion-active impurities formed owing to concentrating in sediments.

To ensure the safe operation of steam generators, heat-exchanging tubes are subjected to nondestructive testing. As a consequence, the tubes with defects impermissible for further operation are blanked off. As a certain number of blanked off HET is achieved, the SG is to be replaced. This is connected with economic losses and radiation exposure for NPP personnel.

The presence of a large number of HET corrosion damages decreases SG reliability and is a dominant factor when a residual operation time and durability of SG are determined. Nevertheless, methods and approaches existing today including standard ones for some reason or other do not always allow us to evaluate a residual operating time of a SG.

Therefore, the increase in reliability and inter-repair life of NPP equipment through the avoidance of unplanned reactor cut-off owing to metal defect of equipment and tubes is extremely important and urgent for electric power production gain in operating NPP power-generating units of SE "NNEGC "Energoatom".

${ }^{*}$ Corresponding author. Email address: stepan.s.lys@lpnu.ua

This paper should be cited as: T. Kovalenko, S. Lys, V. Vostres. Analysis of eddy-current testing and metallographic examinations for corrosion damages of heat exchanging tubes in NPP steam generators. Energy Engineering and Control Systems, 2020, Vol. 6, No. 1, pp. 7 - 15. https://doi.org/10.23939/jeecs2020.01.007 


\section{Analysis of the recent studies and publications}

The experience of operating NPP SG with WWER indicates that the key cause which determines the actual SG lifetime is HET [1], [2]. To make the migration a heat-carrying agent of a primary circuit into a secondary one impossible, all SG undergo regular eddy-current testing (ECT) of HET; as a result, they are preventively blanked off. It should be noted that all the cases of mass HET corrosive damages are relevant to SG, which worked without chemical washing for a long time and with the violation of water-chemical conditions (WCC) [2].

The results based on the analysis of HET corrosive defects of the NPP SG with WWER at Ukrainian and foreign NPP are cited in papers [1], [3]-[7]. It was determined that the corrosion defects on free areas and under spacing elements tend to appear mainly at a bottom of SG tube bundles (Fig.1).

Whereupon the defects on free areas localize mainly near hot header $(\mathrm{HH})$. The defects under spacing grates are also situated at the SG bottom but distributed more evenly along with the tube bundle.

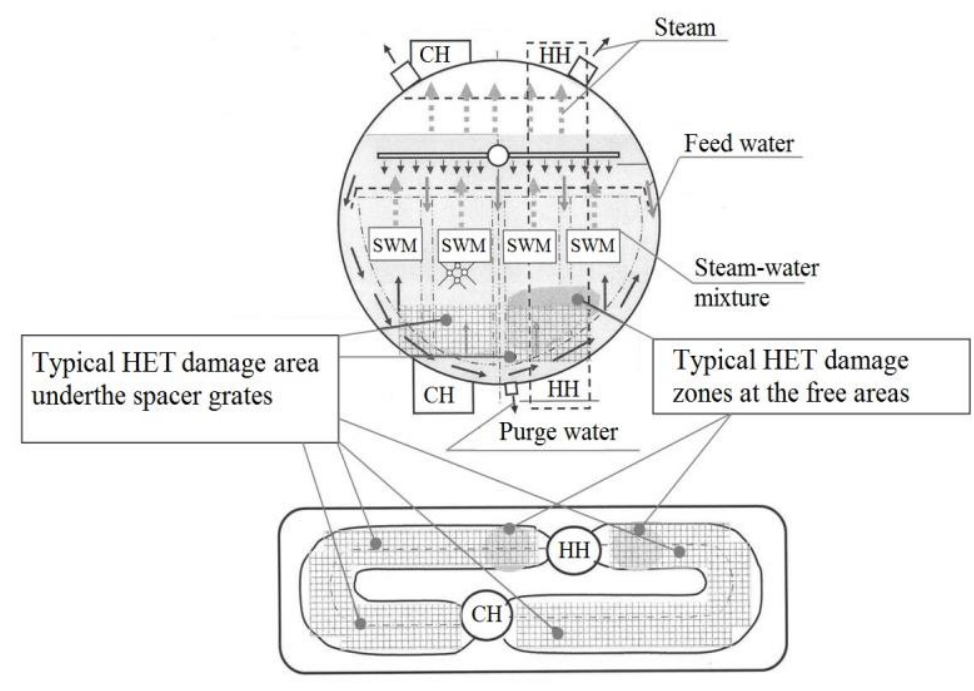

Fig.1. The steam generator in cross section and plan.

On the whole, the SG with HET active degradation is characterized by the formation of so-called "critical areas" where the defects are located.

This is due to sedimentation of corrosion product of significant thickness up to complete blocking between tubes [1], [3]. The analysis of service data indicates that first systematic HET blank off done based on ECT results are carried out after accumulation on the HET surface of the significant sedimentation of corrosion products with specific contamination equal to $300-400 \mathrm{~g} / \mathrm{m}^{2}$ [1].

Thus, the process of HET rusting of the SG can be divided into several consecutive mandatory stages with typical tube degradation mechanism for every phase:

I - the rise in corrosion products at HET to the critical value of specific contamination;

II -accumulation of chlorides and other promoters under scale to the critical value which causes pitting nucleation and corrosion cracking in the presence of an oxidant;

III - pitting nucleation at a critical concentration of chlorides and oxidants;

IV - pitting growth on oxidant transport into the reaction zone;

$\mathrm{V}$ - corrosion crack nucleation with active local plastic deformation in the microvolume of HET metal;

VI - corrosion crack growth before blank off.

Every stage under certain conditions can be observed in SG stationary conditions and nonstationary conditions as well as during an inoperable mode (during the power-generating unit shutdown procedure).

The scale formed by SG operation at power is mainly represented by finely dispersed particles (measuring no more than $10 \mu \mathrm{m}$ ) containing dehydrated oxides, notably the corrosion products of carbon steel and copper alloys 
which are used as a constructional material for a turbine condenser, tubing and condensing-feeding equipment $\left(\mathrm{Fe}_{2} \mathrm{O}_{3}\right.$, $\mathrm{Fe}_{3} \mathrm{O}_{4}, \mathrm{CuO}, \mathrm{Cu}_{2} \mathrm{O}$, etc.). Moreover, the scale often include slightly soluble salts (usually sulphates, silicates, calcium and magnesium hydrates) which infiltrate into condensing-feeding circuit owing to the leakage of cooling water through rolled-on condenser tubes.

The lower scale layers are of low porosity. The HET scale in SG mainly consists of iron oxide (>70\%), copper oxide (is not more than $30 \%$ ) and calcium, magnesium, silicon oxides (1 to 5\% each).

The main mechanism of scale formation is the crystallization of corrosion products from evaporating boiler water, settling finely dispersed impurity particles under the impact of physical and physicochemical driving forces. While scales are forming, during water boiling, a porous continuous canal network grows through which water is fed to HET surface and generated steam is drawn aside.

Taking into account scale porosity and its significant heat conductivity $\left(\approx 1.1 \mathrm{~W} / \mathrm{m}^{2} \mathrm{xK}\right)$ it is worth considering that water boiling inside scale occurs in the sheet of superheated liquid at a HET surface as well as on the surface and within scale (Fig.2). Replacing evaporated water new portions of water come to together with dissolved impurities come to HET surface from flow core. Since the solubility of impurities in steam is lower compared to water, impurities removal by steam does not compensate for their ingress with vaporizing water. Thus, the difference in concentrations between a boundary layer and flow core appears; as the consequence diffusion materializes directed to concentration leveling. At steady-state operation of the SG, the equilibrium condition appears when convective impurity transport is compensated by their steam removal and diffusion.

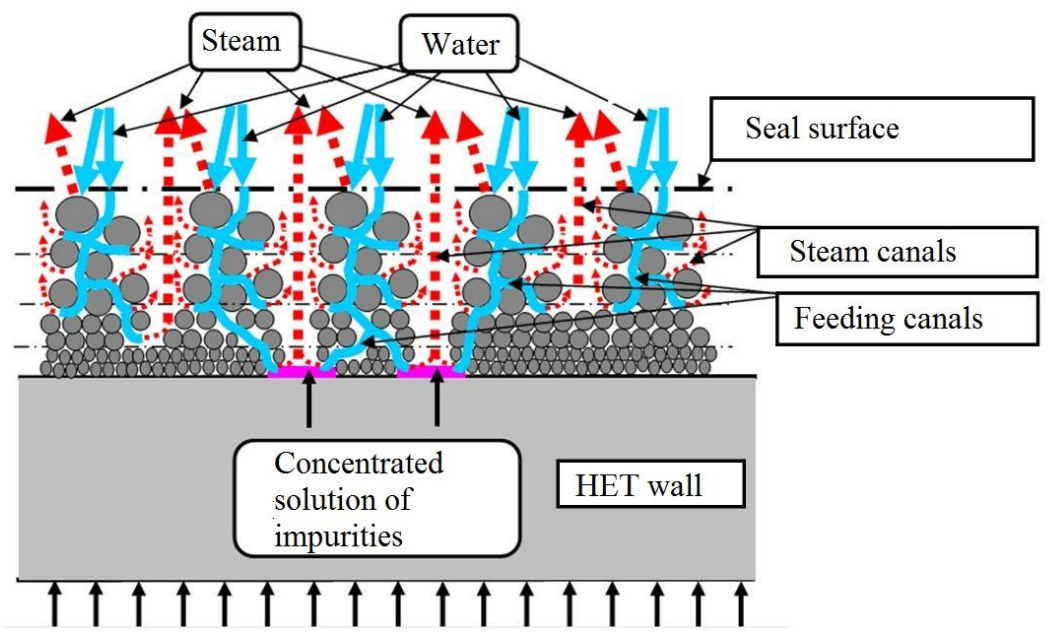

Fig.2. The diagram of water evaporation and impurity concentration under scale at the HET surface.

Since water is strongly polarized solvent $(\varepsilon \approx 80)$ and thus electrolytic solutions are completely or partially dissociated (strong acids, alkali and their salts almost dissociate; weak acids and bases partially). The equilibrium between ions and incompletely dissociated molecules is determined by a dissociation constant.

In $\mathrm{SG}$ water the $\mathrm{Na}^{+}, \mathrm{Cl}^{-}, \mathrm{SO}_{4}{ }^{2-}$ ions are present along with the small quantities of such the ions as $\mathrm{Ca}^{2+}, \mathrm{Mg}^{2+}$, $\mathrm{SiO}_{3}^{2-}, \mathrm{CO}_{3}^{2-}$. While water is boiling, they concentrate in scale pores; by exceeding the solubility the insoluble calcium and magnesium chemicals such as $\mathrm{CaCO}_{3}, \mathrm{CaSO}_{4}, \mathrm{CaSiO}_{3}, \mathrm{Mg}(\mathrm{OH})_{2}$ settle at HET.

When SG is in rated power in the practical absence of oxygen and low water conductivity, the rate of pitting propagation is limited upon the arrival of an oxidant (copper ions for the most part) into the electrochemical reaction zone. Whereupon the electrochemical cell of pitting development is limited by scale thickness and at the initial stage with the area dimensions around the steam canal (Fig.2) where a concentrated solution of salts is located.

Considering the practical absence of oxygen in SG boiling water, the copper ions are the strongest oxidants. Copper appears in scale in an oxide form $\left(\mathrm{CuO}, \mathrm{Cu}_{2} \mathrm{O}\right)$ and specks of metallic copper. In SG water copper is in $\mathrm{Cu}^{2+}$, $\mathrm{Cu}^{+}$ions or a complex compound form. Also, trivalent iron ions $\mathrm{Fe}^{3+}$ can be an oxidant in corrosion processes. But, taking into account a high degree of hydrolysis of the $\mathrm{Fe}^{3+}$ ions in neutral media and extremely low solubility of $\mathrm{Fe}(\mathrm{OH})_{3}$ in water $\left(\approx 0.2 \mu \mathrm{g} / \mathrm{kg}\right.$ at $\left.20^{\circ} \mathrm{C}\right)$, the $\mathrm{Fe}^{3+}$ ions do not play a certain part in HET corrosion. 
At the same time under the influence of formed potential difference the negative ions $\left(\mathrm{OH}^{-}, \mathrm{Cl}^{-}\right)$are transferred within pitting. In so doing, chloride ions, not spent in corrosion, are accumulated inside pitting. During the starting mode and SG rated power operation involving the active local plastic deformation of metal micro volumes at a pitting tip, the nucleation and propagation of corrosion cracks are possible.

As evidenced by the metallographic analysis data, in the bottom of pitting several cracks can simultaneously nucleate, but as one of them propagates (the longest and oriented usually towards the tensile stress), the propagation of other cracks is retarded. Besides, at any moment of development, the main crack can have several branchings.

Based on a literature analysis it is arguable that the considered damaging mechanisms are actually avoidable and can be excluded or minimized on the assumption of [8]:

- avoiding a boundary value excess of HET specific contamination by lowering the ingress of the corrosion products into SG;

- excluding copper-bearing alloys from condensing-feeding equipment of NPP with a WWER ;

- limiting the oxygen access to HET at every phase of the SG life cycle, following the reactor entombment rules.

All this allows arguing that the life cycle of SG with HET from austenitic stainless steel $08 X 18 H 10 T$ can be increased significantly by observing the procedures that must be followed to ensure full compliance with the regulations from the very moment of life cycle beginning.

There are still problems concerning the safe and reliable running of NPP equipment which tend to increase every year. That is why the purpose of this work is the complex analysis of the results eddy-current testing and metallographic examination for HET damaged areas of SG NPP.

\section{Research objectives and methods of examination}

The examinations of HET corrosion defects were conducted on HET models of PGV-1000 SG. SG is horizontal single-case generator with a secondary loop, having a tubular surface, immersed in water, with build-in steam separators, feed water distribution system, steam header with a plunged perforated plate, emergency water feed system. The case in a middle part is welded on to two vertical headers of a primary loop intended for connection with 11000 U-shaped HET. SG HET are the elements of NPP primary loop and are important and simultaneously the most vulnerable from the standpoint of damaging consequents upon corrosion.

Eddy-current testing of HET SG $P G V$ - 1000 is performed either from hot $(\mathrm{HH})$ or cold $(\mathrm{CH})$ the side of headers (see Fig.1) and power unit shutdown for scheduled repair.

ECT is based on the analysis of the interaction between external electromagnetic field induced by an exciting coil within an electroconductive object of research. A coil (one or several), i.e. an eddy-current converter (ECC), is mostly used as a source of the electromagnetic field.

To carry out automatic ECT, the "TEDDY-8" and "MIZ-30" systems were used.

\section{Results of the study}

The study and analysis of ECT HET SG and metallographic investigations of the HET SG were the topics of this paper. All the identified metal defects can be conditionally divided into four parts: the corrosion pitting of different size, the separate cracks, corrosion cracks and corrosion spots on separate metal areas. The representative examples of HET SG defects and the ECT results obtained by ECT systems "TEDDY-8", "MIZ-30" and their comparison are demonstrated further.

Based on the results of the performed analyses, it was determined that corrosion pitting is the most frequent one to occur. The pitting corrosion is known as the most dangerous type of local corrosion. Corrosion pitting defects were conditionally distributed into critical and subcritical during the test performance. Critical defects are those which make a further HET operation dangerous. The tubes having such defects should be blanked off. From the standpoint of ECT, the critical corrosion pitting is characterized by a great percentage of metal loss (from 60 to 100\%) at signal amplitude equal to $10 \ldots 20 \mathrm{~V}$ (Fig. 3, 4 and 5). Characteristic properties of these defects from the metallography standpoint are as follows. In all the analyzed cases these are large corrosion pitting which have round, oval or elongated longwise shape of the tubes. The defects have the dimensions in $2 \ldots 4 \mathrm{~mm}$ range on the tube metal surface. The corrosion products sediments have the intricate shape in the form of coaxial circles positioned around a central hollow - a pitting core. In most cases the cracks are propagated from corrosion pitting predominately longways the tube surface; the cracks may be up to $20 \mathrm{~mm}$ long (see Fig. 5, a). 


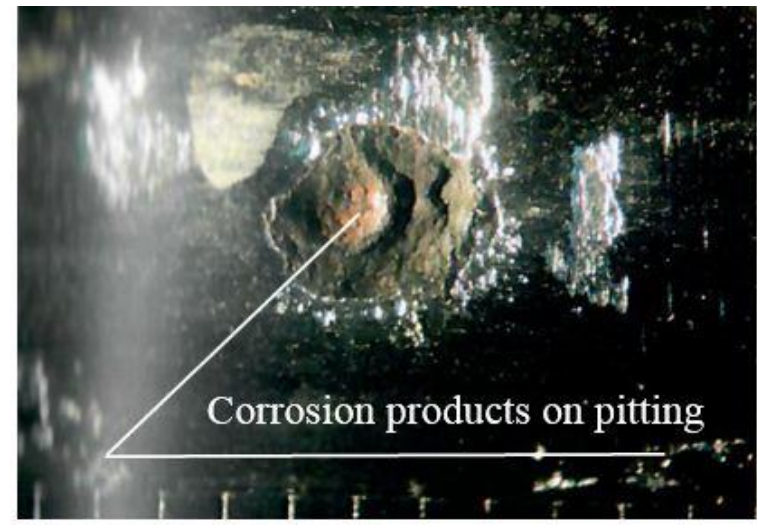

a)

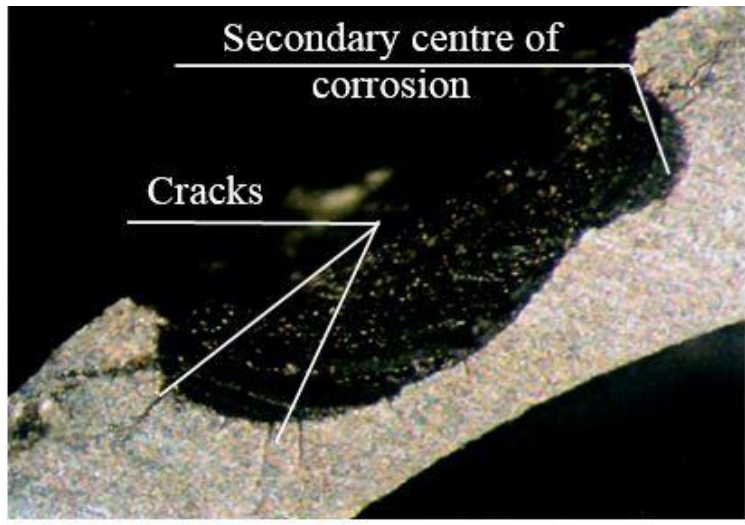

b)

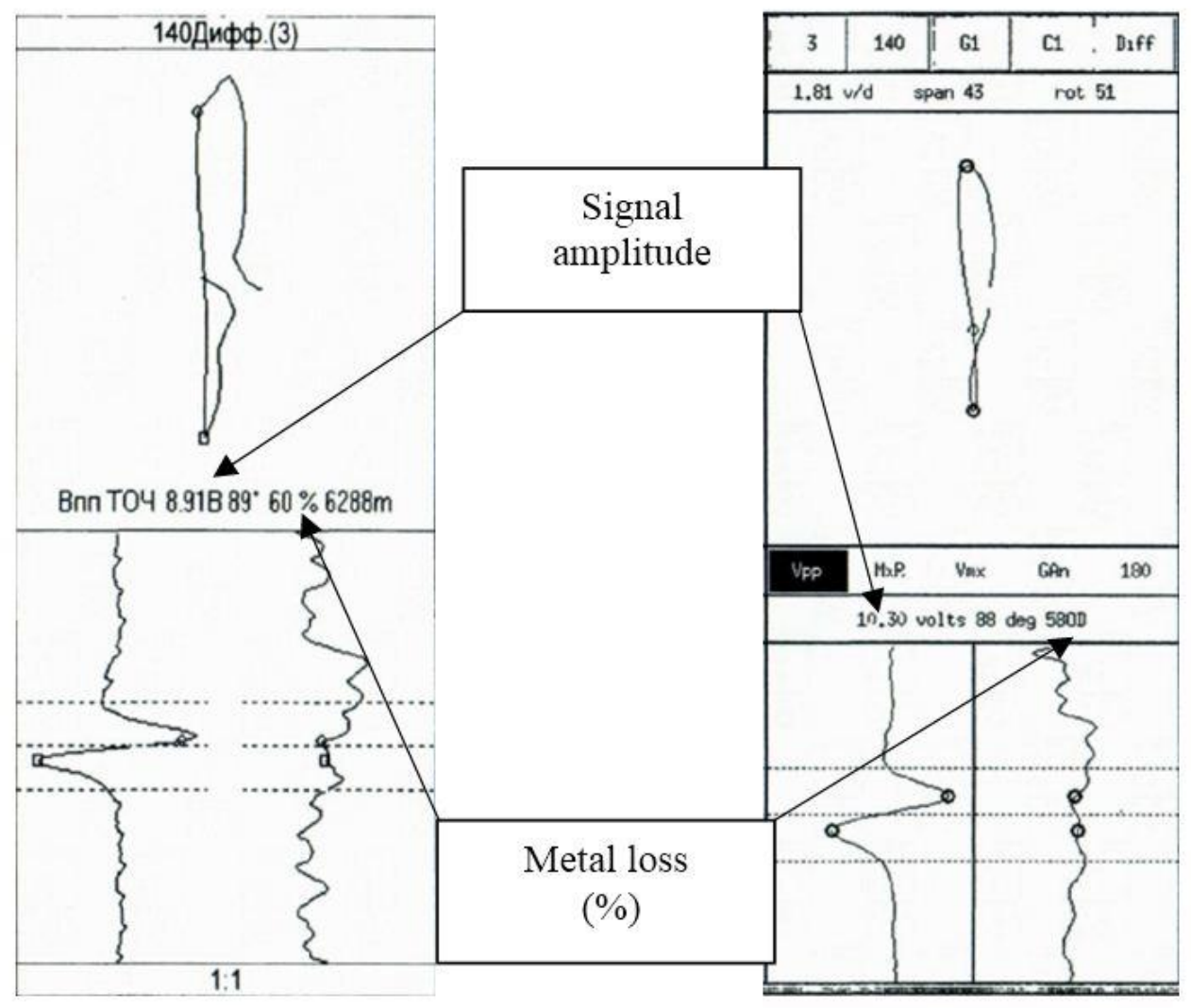

c)

d)

Fig.3. Critical round shape corrosion pitting:

a) Defect appearance on the HET surface;

b) Defect appearance on the metallographic section (metal damage depth up to $1.25 \mathrm{~mm}(83 \%)$;

c) ECT results by "TEDDY-8" system;

d) ECT results by "MIZ-30" system. 


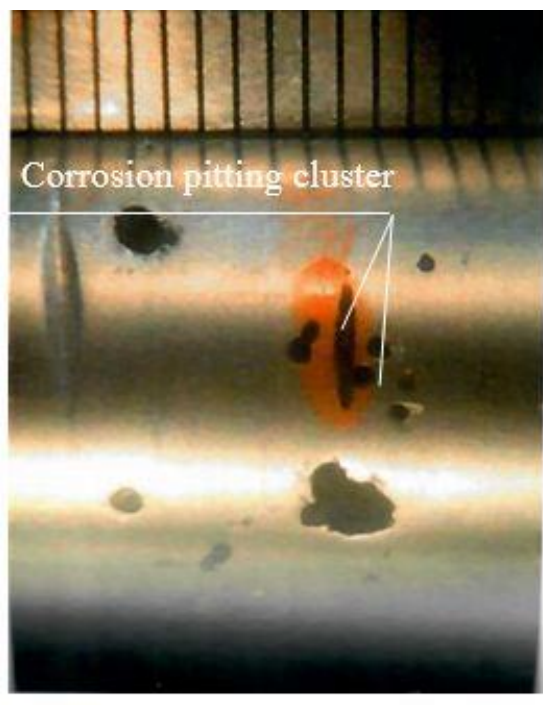

a)

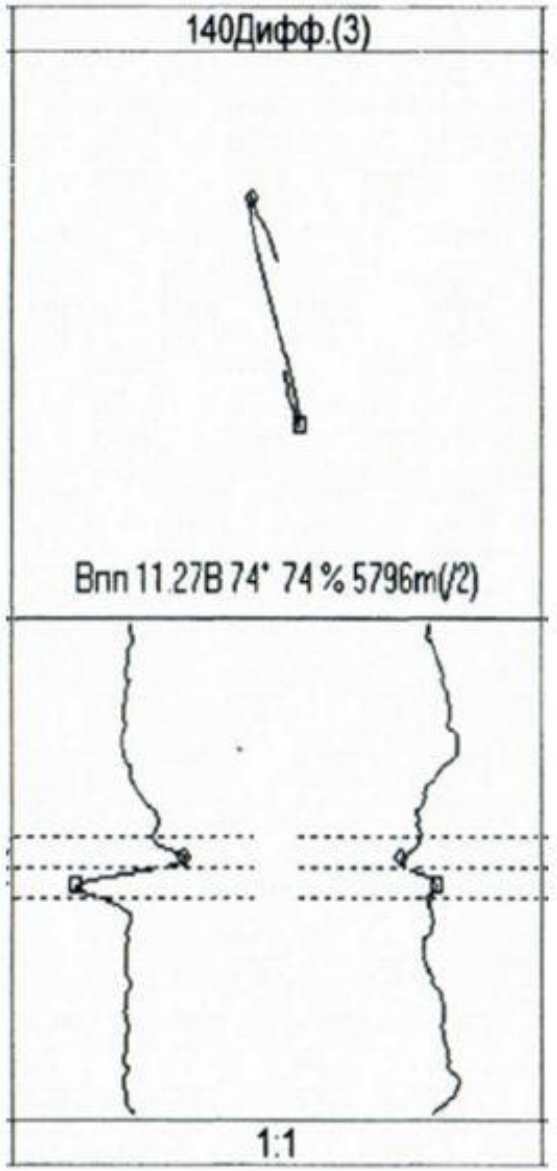

c)

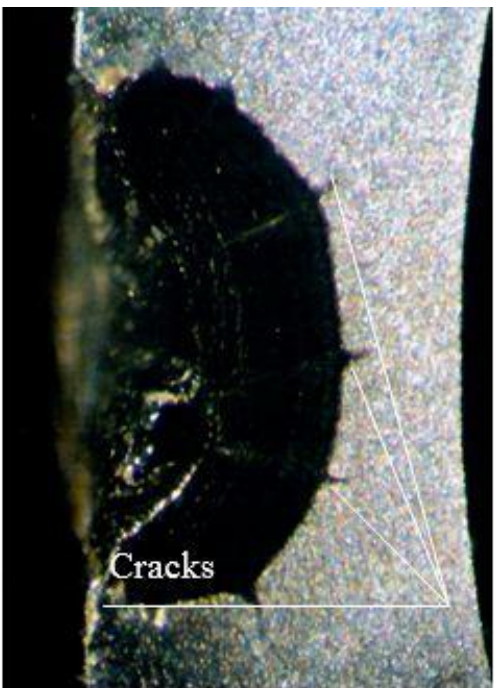

b)

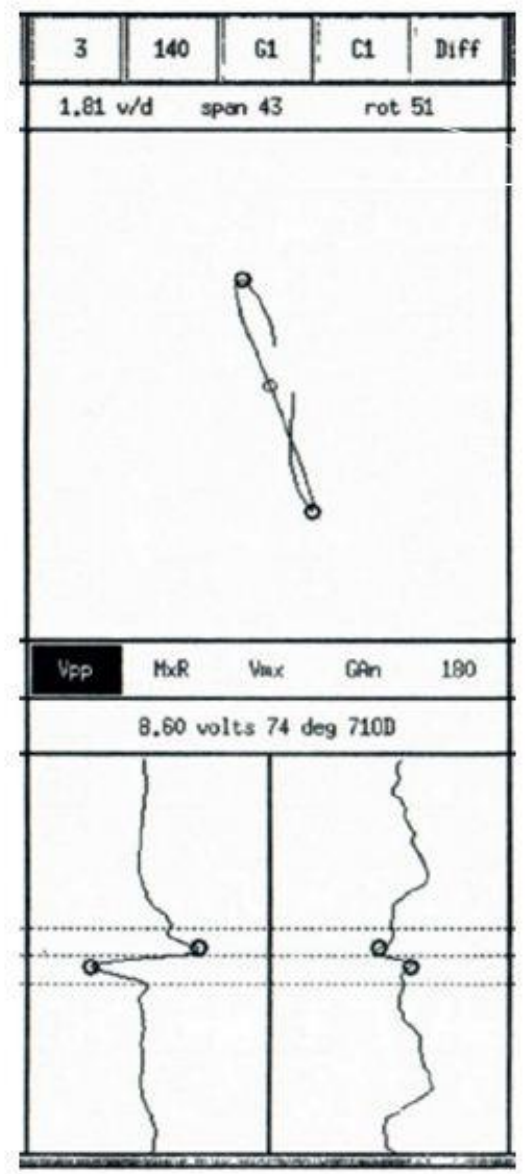

d)

Fig. 4. Critical irregular shape corrosion pitting:

a) Defect appearance on the HET surface;

b) Defect appearance on the metallographic section (metal damage depth up to $1.2 \mathrm{~mm}(80 \%)$;

c) ECT results by "TEDDY-8" system;

d) ECT results by "MIZ-30" system. 


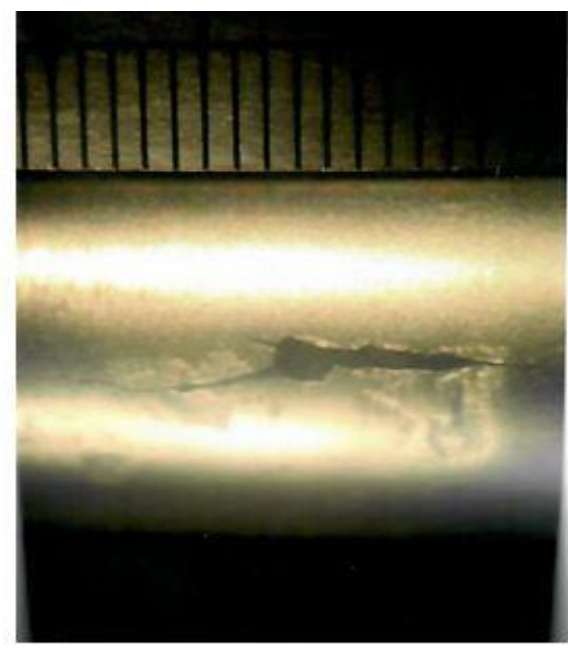

a)

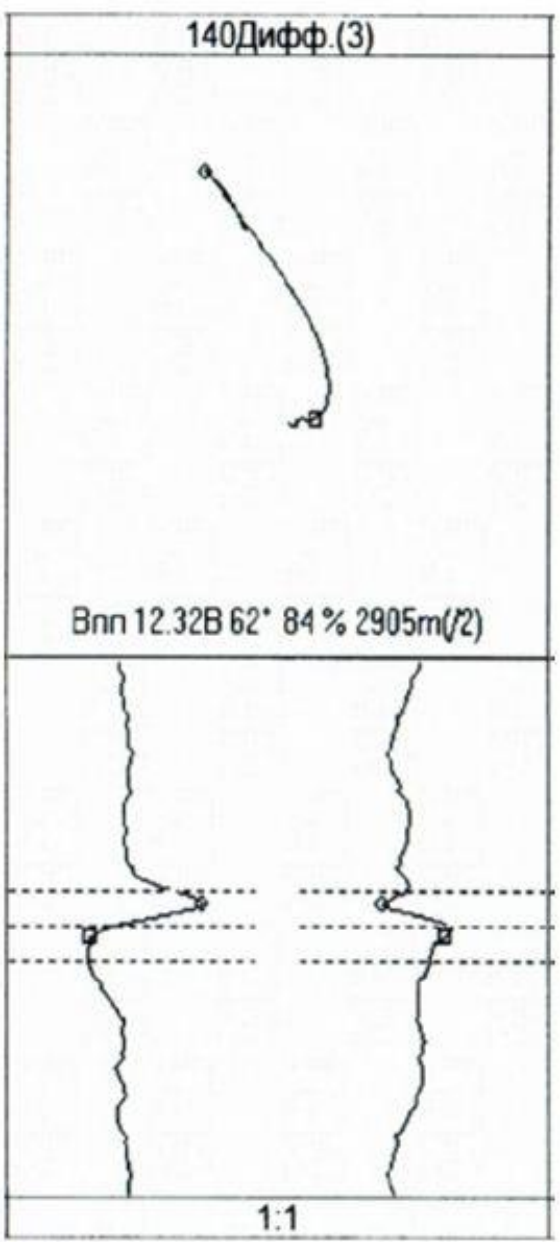

c)

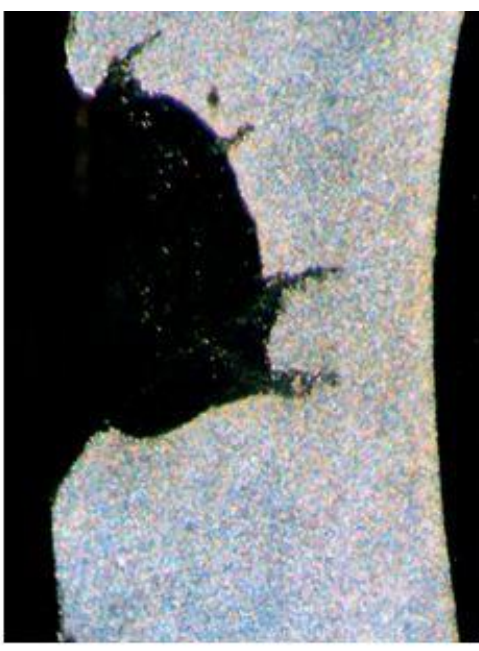

b)

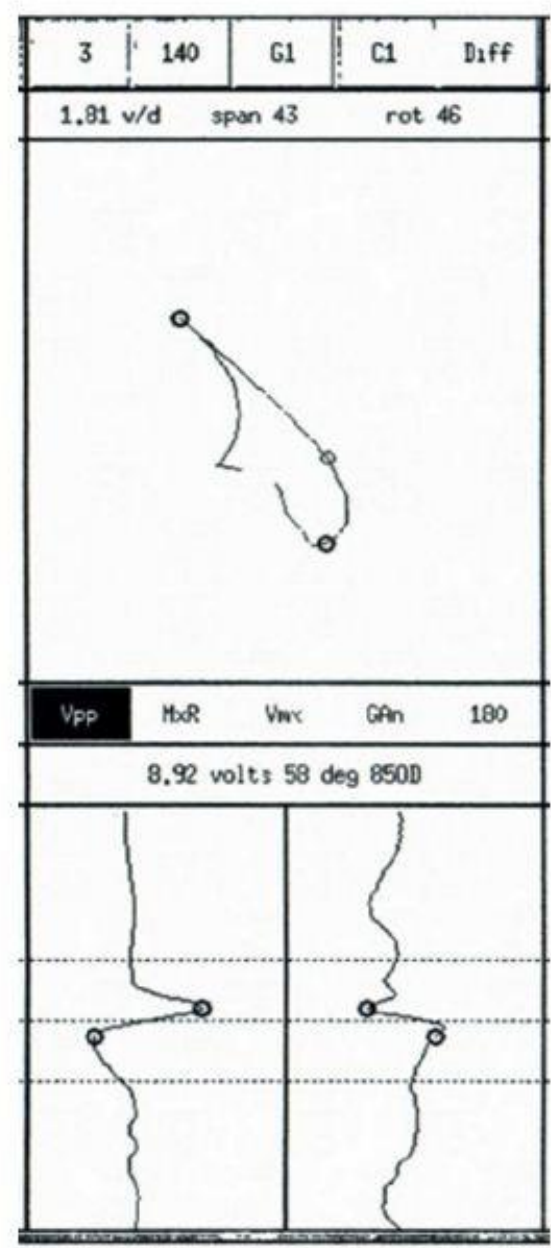

d)

Fig. 5. Critical wedge-shaped corrosion pitting (the total length up to $20 \mathrm{~mm}$ ):

a) Defect appearance on the HET surface;

b) Defect appearance on the metallographic section (metal damage depth up to $1.32 \mathrm{~mm}(88 \%)$;

c) ECT results by "TEDDY-8" system;

d) ECT results by "MIZ-30" system. 
The metallographic section in cross section represents the corrosion pitting as a hollow in metal mainly an oval shape which begins on the tube surface. In all the cases the hollows are filled with corrosion sediment with typical layer structure. The cracks propagate into metal from large pitting. In pitting with cracking the framework structure of sediment is observed. Besides the metal cracks are perpendicular to the sediment layers (see Fig. 4, b). Some defects have almost regular oval shape. In the centre is situated the pitting nucleus, around which the layers of corrosion sediment are formed. Other corrosion pitting of the irregular shape as a result that corrosion centres have two or more nuclei. The crack emergence also deforms the pitting shape.

The comparative analysis for the measuring data of the metal loss obtained by ECT "TEDDY-8" and "MIZ-30" systems shows good enough correspondence for all the analyzed defects (Fig. 3 c, d; Fig. 4 c, d; Fig, 5 c, d). A percentage of the damaged metal according to the metallography exceeds the ECT data in all the analyzed cases. Predominantly the difference is equal to $10 \ldots 15 \%$, in separate cases up to $25 \%$ (Fig.3). The probable cause of ECT understating data for a defect depth may be in metal loss data averaging along a length of more than $1 \mathrm{~mm}$. It is necessary to take this fact into account while deciding about the tube blank off after testing.

The measured signal amplitudes obtained by ECT "TEDDY-8" and "MIZ-30" systems vary within 20...30\% range (Fig. 3 c, d; Fig. 4 c, d; Fig. 5 c, d). Such a difference in readings may be attributed to calibration differences, distinctions in used probe specifications, constructive peculiarities and system software.

In essence, the signal amplitude against the defect characterizes the bulk component of the damaged metal in the tube and is the composite function of the depth, length and width of the defect including cracks and other defects in testing zone. The estimation of the bulk component for corrosion pitting is problematic. There is no something like the dependence between amplitude value and critical pitting geometry.

HET operation with subcritical defects is possible, of course, with the regular control ensured. Such a possibility is based on the assumption that the fast growth of the defects stops and they will not be identified until the next examination. In many instances, the tubes having subcritical defects are in long term operation up to the formation of other defects.

\section{Results and discussion}

Based on the result of the analysis, it is possible to assert that corrosion pitting is the most prevalent in SG HET; among which the critical defects occur the most frequently and further operation is dangerous.

ECT results obtained by diverse systems mainly correlate well. The control parameters "amplitude-signal" and "metal loss" are dependent on calibration, probe characteristics and system software. The parameter "phase" is independent of calibration. The ECT results according to this parameter are the most correspondent between the two control systems.

A certain distinction present between the measuring data of the defect depth by ECT and metallographic methods may be accounted for that at the research zone two or more defects are found, but ECT system detects all them as one (integrating the results). The conducted analysis shows that the parameter "metal loss" in most cases corresponds with the deepest defect and is linear dependent. The defect quantity is represented as signal amplitude.

When making a decision on SG HET blank off based on ECT results, it is necessary to estimate the possible opening of the detected defect, namely the possibility of leak and its size provided that operation continues. Therefore, based on metallography, the most dangerous are the defects of a corrosion pitting type, though this conclusion can be made not only after the scrutinizing the metallographic section. As a rule, the pitting is filled with corrosion products, i.e. oxides. The investigations showed that oxidation is accompanied by expansion with any possible reagents. This leads to bursting stress inside the pitting and consequently to tensile stress around. As a result, we have metal cracking around the pitting, mainly longitudinal ones. The mechanism and growth kinetics of corrosion pitting are not fully investigated for now. The regularities of their growth stopping are not clear. But even if oxidation stops stress is still observed in the pitting in the surrounding metal due to metal heterogeneity which appears particularly owing to distinction in thermal expansion coefficient. Thus, the tendencies towards crack propagation are still displayed and the possibility of tube leak is preserved respectively. The leak value immediately after its identification is proportional to pitting area and may appear to be critical.

Thus, the course of corrosion processes on HET surface for various SG operational conditions is peculiar. These processes are not always inevitable and may be eliminated or minimized if we follow the below rules:

- avoidance of exceeding the limiting specific contamination at HET by limiting the corrosion product ingress into SG; 
- exclusion of copper-bearing alloys from condensation-feeding equipment of NPP with WWER-1000 reaction plant;

- limitation of oxygen access to HET during SG life cycle, observing the conservation rules.

\title{
6. Conclusion
}

This paper discusses mechanisms of corrosion damage for heat-exchanging tubes (HET) of a PGV-1000 steam generator (SG), the effect of different SG operation conditions that influence the HET corrosion damages. The analysis and classification of the defects which form in SG HET was performed, as was the comparative analysis of eddy-current testing (ECT) which was formed by two various ECT "TEDDY-8" and "MIZ-30" systems (according to the signal amplitude and "metal loss") and juxtaposed with metallographic analysis data. According to the ECT data, the peculiarities of current-carrying sediment on the SG HET within so-called "critical zone" where the defects localize were confirmed.

\section{References}

[1] N. B. Trunov, S. A. Lohvinov, Y. H. Drahunov. Hydrodynamic and thermo-chemical processes in steam generators of NPP with WWER. M.: Energoatomizdat, 2001, 316. (in Russian)

[2] S. I. Brykov, H. F. Banyuk, N. B. Trunov, Y. V. Kharytonov, S. N. Susakin, N. N. Davydenko. Role of water-chemical regime of second contour in resource management for steam generators of NPP with WWER // WANO and IAEA Workshop "Optimisation of steam generators operating regimes for NPP power units", Rivne NPP, Ukraine, June 11-14, 2002. (in Russian)

[3] "Report on the condition of steam generators PGV-440 and PGV-1000 of power units of Ukrainian NPPs for 2012", approved on 09.07.2013. (in Russian)

[4] I. M. Neklyudov, V. M. Azhazha, A. S. Mytrofanov, L. S. Ozhyhov, E. A. Kraynyuk, V. H. Lesnaya, P. A. Mishchenko. Atlas of operational defects in the heat transfer tubes of steam generators of nuclear power plants with WWER-type reactors: Directory-catalog. Intellectual property of National Science Center, Kharkiv Institute of Physics and Technology, Certificate No. 20514, Kharkiv, 2012, p. 237. (in Russian)

[5] V. N. Voevodyn, A. S. Mytrofanov, S. V. Hozhenko, R. L. Vasylenko, I. N. Shapoval, E. A. Kraynyuk, A. V. Bazhukov, A. N. Paliy, P. E. Melnyk. Analysis of data on monitoring the heat exchanging pipes of PGV-1000 steam generators at the South-Ukraine NPP // Issues of nuclear science and technology, 2018, No. 5 (117), p. 82-86. http://dspace.nbuv.gov.ua/handle/123456789/147705. (in Russian)

[6] J. Degmová, J. Dekan, V. Slugeň, C. Thees, I. Smieško, P. Šeliga. Analysis of steam generators corrosion products from slovak NPP Bohunice // International Journal of Corrosion, 2012, Volume 2012, 1-6. https://doi.org/10.1155/2012/643727

[7] G. Shimov, A. Serebryakov, A. Serebryakov. Experimental study of the method for resistance heat treatment of tubes for steam generator // Key Engineering Materials, 2017, Vol. 74, 141-147. https://doi.org/10.4028/www.scientific.net/KEM.746.141

[8] PN-D.0.03.539-14. Action plan to improve the reliability of steam generators and condensers of NPP turbine units of National Nuclear Energy Generating Company "Energoatom” for the period 2014-2020, p. 27. (in Russian)

\section{Аналіз результатів вихорострумового контролю та металографічних досліджень корозійних дефектів теплообмінних труб парогенераторів АЕС}

\author{
Тетяна Коваленко, Степан Лис, Володимир Вострес \\ Національний університет «Львівська політехніка», вул. С. Бандери 12, Львів, 79013, Украӥна
}

\section{Анотація}

Розглянуто механізми корозійних пошкоджень теплообмінних труб (ТОТ) парогенератора ПГВ-1000 у різних режимах його роботи. Встановлено, що корозійні дефекти локалізуються переважно в нижній частині трубних пучків парогенератора. Проведено дослідження корозійних пошкоджень теплообмінних труб парогенератора ПГВ-1000. Виконано порівняльний аналіз результатів вихорострумового контролю (ВСК) ТОТ парогенератора отриманих за допомогою двох різних систем ВCK «TEDDY-8», «MIZ-30» та співставлення цих даних із результатами металографічних досліджень дефектів. Встановлено, що відсоток ураження металу за результатами металографії для абсолютної більшості проаналізованих дефектів перевищує дані ВСК. В основному різниця становить $10-15 \%$, в окремих випадках - до $25 \%$. Доведено, що тонкостінні ТОТ парогенератора не повинні мати значних або наскрізних дефектів з метою забезпечення надійної роботи ТОТ ПГВ1000, що є однією з найважливіших задач на АEC.

Ключові слова: парогенератор; теплообмінні труби; корозійні дефекти; вихорострумовий аналіз; металографічні дослідження. 